\title{
Measuring Growth of Labor Productivity in Vietnam by Shift-Share Analysis of Structure of Industries
}

\author{
NGUYẼ̃N QUỐC TẾ \\ University of Economics HCMC \\ Email: htqtnqt@ueh.edu.vn \\ NGUYẼ̃N THI ĐÔNG \\ Banking Academy, Phú Yên \\ Email: dong283vn@yahoo.com
}

\begin{tabular}{ll} 
ARTICLE INFO & ABSTRACT \\
\hline $\begin{array}{l}\text { Article history: } \\
\text { Received: }\end{array}$ & $\begin{array}{l}\text { This research aims at measuring growth of labor productivity during } \\
\text { March 27, 2013 } \\
\text { structural changes in Vietnam in the years 1994-2011. Shift-share } \\
\text { analysis of structure of industries shows that growth of labor } \\
\text { productivity in Vietnam is a result from the static shift effect. In other } \\
\text { May 31, 2013 } \\
\begin{array}{c}\text { Accepted: } \\
\text { Sep. 25, 2013 }\end{array}\end{array}$ \\
$\begin{array}{l}\text { words, productivity growth is resulted from changes in structure of } \\
\text { industries, in which labors move from low-productivity industries to } \\
\text { higher ones. Both endogenous (within-industry) factors and dynamic } \\
\text { shift effect seem to be affected by the burden of structure and the } \\
\text { backwardness of technology in the process of economic structural } \\
\text { labor productivity, } \\
\text { shift in structure of } \\
\text { industries. }\end{array}$ & changes. \\
\hline
\end{tabular}




\section{INTRODUCTION}

Boosting the labor productivity is to ensure development of production and human life, especially increases in volume of products and services offered. Higher productivity is a decisive factor in improvements in national competitivenes, and international cooperation and integration.

Changing the economic structure by boosting the labor productivity, according to government, is an indispensable way for the country to develop from a poor and backward nation into a civilized and modernized one. This process, however, does not generate a really sustainable growth of labor productivity. Therefore, it is truly meaningful to identify which element of economic structural change can generate a higher labor productivity.

\section{THEORETICAL BACKGROUND}

\section{a. Labor Productivity:}

Labor productivity is a measurement of effectiveness of using labor in production characterized by a comparative relationship between amount of goods or services produced and the labor used to produce them. With each economic entity, as company and other types of enterprises, the labor productivity is measured by the total output produced in an hour of working, or the period of time needed to produce a unit of output. At the national level, it is called productiviy of social labor (LP), which is measured by the real GDP or GNP divided by the number of labors working in a given period (L).

$$
\mathrm{LP}=\frac{\mathrm{GDP}}{\mathrm{L}}
$$

Growth of labor productivity refers to increases in production capacity and changes in working methods that aim at reducing the time needed for producing a product so that a smaller amount of labor can produce a larger use value (Trần \& Mai, 2012). This is a limitless way to increase gross social product because it depends on techno-scientific advances which is proved to be unlimited in reality. Therefore, the Vietnamese government determines that growth of labor productivity is an issue of the greatest importance as one of three strategic breakthroughs for changes in economic growth model and economic restructuring. Moreover, it is considered as the most important competitive advantage that ensures a rapid, effective and sustainable development (Nguyễn, 2011). 


\section{b. Changing the Structure of Industries:}

Structure of industries is the relation between industries of the economy reflecting an organic relationship and the quantitative and qualitative interaction between industries. This structure always changes over time due to its unstable components. The process in which this structure grows into a better state more appropriate to development environment and this condition is called structural change. (Phạm Ngọc Linh and Nguyễn Thị Kim Dung, 2011)

On the aspect of economic growth and development, the structure of industries is considered as an important and most-explored factor because it reflects development of technology, science, production force, division of labor, specialization and cooperation. Its condition reflects level of economic development of each country. Structural change is a continous process and associated with economic development. Moreover, development speed and sustainability of economic growth depend on flexibility of structural change that is appropriate to external and internal conditions and relative advantages of the economy as well.

\section{c. Relationship between Growth of Labor Productivity and Structural Change:}

Examining impact of changes in economic structure on the growth rate of labor productivity, most economists assume that growth of labor productivity may be the result of changes in structure of industries when other factors such as equipment, labor/capital, and labor quality, etc. remain unchanged. According to dual-sector model introduced by W.A. Lewis, the economy of an underdeveloped country can be divided into 2 sectors: a traditional agricultural sector with low productivity and an industrial sector with a higher one. The former has a surplus of unproductive labor while the latter enjoys higher employment and wage rate. Thus, flow of laborers from agricultural sector to industrial one can help increase the labor productivity of the whole economy (E.Wayne Nafziger, 1998).

This situation also occurs in every sector. For example, in manufacturing sector, there are flows of labor from the low-productivity industries (such as textile and clothing) to the one with higher productivity (such as electronic or engineering industries). Such movement also makes the overall labor productivity of the economy increase. Additionally, if the labor moves in the opposite direction, from higher-productivity industries to the lower ones, resulting changes in economic structure will reduce the overall productivity (Nguyễn Thị Lan Hương, 2007). 
In sum, if growth of labor productivity is considered as the engine of the structural change, such a change also serves as a lubricant for that engine, otherwise the growth of labor productivity cannot be maintained.

\section{QUANTIFICATION OF IMPACT OF STRUCTURAL CHANGE ON GROWTH OF LABOR PRODUCTIVITY}

\section{a. Shift-share Analysis of Structural Change:}

The shift-share analysis examines growth of labor productivity through movements of structure of industries and level of shift in labor structrure by industry.

This method, used for measuring amount of labor per unit of output, was built by S. Fabricant (1942). Afterwards, other economists like M. Syrquin (1984), J. Fagerberg (2000), and M. Timmer \& A. Szirmai (2000) employed this method in the opposite direction: measuring the volume of output produced per unit of labor.

With LP as aggregate labor productivity; $i$ as industries $(i=1, \ldots, n$, where $\mathrm{n}$ is the number of industries); $S_{i}$ as ratio of labor working in industry $i$ to the workforce; 0 and $t$ as beginning and finishing time of the research, gross labor productivity at time $t$ in Equation (1) can be as follows:

$$
L P^{t}=\frac{G D P^{t}}{L^{t}}=\sum_{i=1}^{n} \frac{G D P_{i}^{0} \cdot L_{i}^{t}}{L_{i}^{t} \cdot L^{t}}=\sum_{i=1}^{n} L P_{i}^{t} \cdot S_{i}^{t}
$$

Equation (2) is used for calculating the difference in aggregate labor productivity at times 0 and $\mathrm{t}$ (Timmer \& Szirmai, 2000):

$$
\begin{gathered}
L P^{t}-L P^{0}=\sum_{i=1}^{n} L P_{i}^{0}\left(S_{i}^{t}-S_{i}^{0}\right)+\sum_{i=1}^{n}\left(L P_{i}^{t}-L P_{i}^{0}\right) \cdot\left(S_{i}^{t}-S_{i}^{0}\right) \\
+\sum_{i=1}^{n}\left(L P_{i}^{t}-L P_{i}^{0}\right) \cdot S_{i}^{0}
\end{gathered}
$$

Dividing two sides of Equation (3) by $L P^{0}$, we obtain the formula for growth rate of aggregate labor productivity:

$$
G L P_{t}=\frac{L P^{t}-L P^{0}}{L P^{0}}=\frac{\sum_{i=1}^{n} L P_{i}^{0}\left(S_{i}^{t}-S_{i}^{0}\right)}{L P^{0}}
$$




$$
+\frac{\sum_{i=1}^{n}\left(L P_{i}^{t}-L P_{i}^{0}\right)\left(S_{i}^{t}-S_{i}^{0}\right)}{L P^{0}}+\frac{\sum_{i=1}^{n}\left(L P_{i}^{t}-L P_{i}^{0}\right) S_{i}^{0}}{L P^{0}}
$$

Growth rate of aggregate labor productivity as measured by Equation (4) is based on three parts: the first term of the right-hand side of equation denotes static shift effect, the second denotes dynamic shift effect and the last denotes within-industry productivity growth (Timmer \& Szirmai, 2000).

Static shift effect measures the growth rate of aggregate labor productivity through shifts in labor structure from low-productivity industries to high-productivity ones using value of labor productivity of the industry in the first year of researching period. According to Chenery et al. (1986), the capital-to-labor ratio in light industries is lower than that in heavy ones, and transfer of labor from light industries to heavy ones tends to make aggregate labor productivity increase because capital-intensive industries usually obtain a higher labor productivity.

Static shift effect, moreover, plays an important role to developing countries, especially agricultural countries where population density is high and idle or redundant labor is common. Transfer of labor from agricultural sector with low labor productivity to industrial one with higher labor productivity is therefore considered as "a structural bonus" for developing countries (Timmer \& Szirmai, 2000). That means the hypothesis of "structural bonus" is based on expectation that contribution from static shift effect to growth of the productivity of social labor is positive:

$$
\frac{\sum_{i=1}^{n} L P_{i}^{0}\left(S_{i}^{t}-S_{i}^{0}\right)}{L P_{i}^{0}}>0
$$

Unlike static shift effect that only reflects transfers to high-productivity industries, dynamic shift effect measures the growth of aggregate labor productivity based on changes in both labor productivity and speed of growth of labor productivity in the industry (If the labor moves to industries where both labor productivity and its growth rate are high) it may make the aggregate labor productivity increase and positive interactive effects greater. Contrarily, the economy may suffer a slowdown when the labor moves from high-growth-rate and high-productivity industries to traditional ones characterized by a low productivity. W. Baumol (1967) called it a "structural burden" in the labor reallocation in each industry. Thus, the dynamic shift effect will be negative when a structural burden appears: 


$$
\frac{\sum_{i=1}^{n}\left(L P_{i}^{t}-L P_{i}^{0}\right)\left(S_{i}^{t}-S_{i}^{0}\right)}{L P_{i}^{0}}<0
$$

The last effect of the growth of aggregate labour productivity is within-industry productivity growth that reflects improved labor productivity when no shift in labor structure occurs and the size of labor force in each industry remains unchanged during the researching period. This component can be considered as total factor productivity because growth of labor productivity is also a result of not only shift in labor structure, but also application of technological advances, improvements in technical effect by improving method of management, training, and enhancement of labor skill and quality, etc. All of these factors are included in within-industry productivity growth.

\section{b. Description of Data for Analysis:}

Applying the shift-share analysis to structural change as presented above, this research uses the data set of Asian Development Bank (ADB) in the period 1994-2011 about the labor and GDP by industry of Vietnam's economy (agirculture, industry, service) expressed in 1994 comparative price. Calculation of data of 2012 is based on data supplied by GSO. Comparison of data on labor and GDP in recent years from these two sourses reveals no difference, so the research result is not affected. Equation (4) based on aforementioned numerical data reflects levels of impact of shift effects on the growth of aggregate labor productivity.

\section{c. Calculation Results:}

This research comprises five stages for calculation and examination of two aspects: increase or decrease of each components in the growth of aggregate labor productivity at each stage; and the share of contribution from components to the growth of aggregare labor productivity in general.

Table 1: Changes in Labor Productivity in Vietnam over time (\%)

\begin{tabular}{lccccc}
\hline \multicolumn{1}{c}{ Stage } & $\mathbf{1 9 9 4 - 1 9 9 7}$ & $\mathbf{1 9 9 7 - 2 0 0 0}$ & $\mathbf{2 0 0 0 - 2 0 0 4}$ & $\mathbf{2 0 0 4 - 2 0 0 8}$ & $\mathbf{2 0 0 8 - 2 0 1 2}$ \\
\hline Changing rate of component & & & & & \\
Static shift effect & 0.66 & 12.30 & 12.36 & 19.68 & 8.04 \\
$\begin{array}{l}\text { Dynamic shift effect } \\
\begin{array}{l}\text { Within-industry growth of } \\
\text { labor productivity }\end{array}\end{array}$ & 0.26 & -1.32 & 0.74 & -4.00 & -0.088 \\
& & -4.19 & 4.73 & 3.66 & -0.187
\end{tabular}




\begin{tabular}{|c|c|c|c|c|c|}
\hline $\begin{array}{l}\text { Labor productivity growth } \\
\text { rate }\end{array}$ & 20.67 & 6.79 & 17.83 & 19.34 & 7.85 \\
\hline \multicolumn{6}{|l|}{ Share of components } \\
\hline Static shift effect & 3.19 & 181.15 & 69.32 & 101.76 & 102.5 \\
\hline Dynamic shift effect & 1.26 & -19.44 & 4.15 & -20.68 & -0.11 \\
\hline $\begin{array}{l}\text { Within-industry growth of } \\
\text { labor productivity }\end{array}$ & 95.55 & -61.71 & 26.53 & 18.92 & -2.39 \\
\hline Total & 100.00 & 100.00 & 100.00 & 100.00 & 100.00 \\
\hline
\end{tabular}

Source: Calculated from ADB's data

According to our calculations, components that contribute to the growth of labor productivity in Vietnam change differently over researching stages. In the period 19941997, the within-industry labor productivity (i.e. replacement of technology, technical innovation, skill and management, etc.) made the aggregate labor productivity increase by 19.75 percentage points accounting for $95.55 \%$ of growth of the labor productivity while in periods 1997-2000 and 2008-2012, this component produced a negative growth rate. It is considered as a proof application of technical advances, new technology, and modern equipment and machinery can only increase the labor productivity to a limited extent.

The within-industry labor productivity, in the later stages, did not remain stable and play a decisive role in the growth of aggregate labor productivity as the static shift effect. Our survey finds that the transfer of labor from agriculture, forestry and fishery to industry, construction and trading service with higher productivity occurs strongly and impacts effectively on the aggregate labor productivity. In periods 1997-2000 and 20042008 in particular, this transfer made labor productivity rise by 12.36 and 19.68 percentage points respectively contributing $181.15 \%$ and $101.76 \%$ to the growth rate of aggregate labor productivity. This finding reflects the Lewis' theory of transfer of labor from agriculture to industry in a newly industrialized country when a labor surplus exists in the agricultural sector.

The highly significant result of static shift effect in Vietnam implies that high growth of labor productivity in Vietnam in its first period of industrialization can be achieved by a simple transfer of surplus labor from agricultural sector to non-agricultural sectors where the labor productivity is much higher. 
Finally, dynamic shift effect can only make small contributions to growth of aggregate labor productivity in most surveyed periods. Two surveyed stages even witnessed negative dynamic shift effects when its contributions were $-19.44 \%$ and $20.68 \%$ respectively, which implies that growth of aggregate labor productivity in industry and service sectors is stagnant and lower than that in agicultural sector producing a "structural burden" for the economy.

This burden simply comes from the fact that part of Vietnamese labor force, because of its poor skill and low cost, only moves among labor-intensive industries, instead of capital- and technology-intensive ones, and produces low growth rate of productivity. In agricultural sector, meanwhile, labor productivity is increasing rapidly because transfer of labor reduces the labor force in this sector while biotechnological advances and new machines are applied more effectively, which makes the labor productivity increase faster. The structural burden will appear and exist if manufacturing, construction and service sectors cannot improve their labor productivity.

\section{CONCLUSION AND POLICY RECOMMENDATION}

Growth of aggregate labor productivity and shift in economic structure are two central problems to the economic growth. Examining their relationship amounts to seeking for the optimal solution to the problem. The research results show that recent growth of labor productivity in Vietnam mostly depends on the transfer of labor from a low-productivity agricultural sector to higher-productivity service and manufacturing sectors. However, it also indicates that the slow growth of labor productivity in manufacturing and service sectors shows that it is achieved mainly by expanding laborintensive industries based on cheap and abundant labor from agricultural sector instead of improvements in technology or skill.

According to the survey titled "Shortage of Skilled Labor in Vietnam" conducted by Institute of Labor Science and Social Affairs (Ministry of Labor, War Invalids and Social Welfare) in cooperation with Manpower Group among 6,000 enterprises of nine industries in nine cities/provinces of Vietnam, the enterprises reveal that the quality of Vietnamese laborforce is among the lowest 10 per cent group in Southeast Asia. Of surveyed enterprises, a quarter of them said that local labor lacked creative ability and knowledge about technology; one fifth commented that it lacked ability to adapt new technology; one third could not recruit skilled labor, and two fifths of Chief Executive Officers met difficulties in recruiting workers (Dũng Hiếu, 2012). 
As estimated by various economists, cheap labor in Vietnam is still an advantage but it has no future because Vietnam cannot gain high growth rates in coming years relying on this advantage (Lê Phái, 2010). Thus, government needs to concern about the following solutions in order to enhance the aggregate labor productivity:

Firstly, restructuring should be carried out continuously in all industries and the whole economy as well. In the past, billions of dollars worth of tax incentives have been given to such industries as automobile, steel, and ship building, etc., in an effort to turn Vietnam into an industrialized country by 2020 . However, no numerical data prove that they are big advantages and promising fields for Vietnam in the future, because in past years, development of those industries has only based on some different elements instead of Vietnam's inner resources.

After over 20 years of economic reform, meanwhile, Vietnam has become a major exporter of various agricultural products and household goods such as pepper, rice, coffee, green tea, aquatic products, textile, footwear and furniture by making the best use of its comparative advantages. Although production of these goods helps reduce unemployment and improve the living standards for the majority of people, relevant industries can only produce semi-finished goods or act as subcontractors for foreign partners, and investment in stages that generate higher added value is not high enough. Thus, all industries should be structured in an overall effort to develop new products from existing ones, especially goods for export, in order to promote the national potentials.

Secondly, in order to facilitate the restructuring of industries and lines of products, government needs to change the structure of public investment by giving priority to industries demanded by agricultural and rural development, such as farm machinery, post-harvest solutions, and farm product processing with high- and eco-friendly technologies and by encouraging development of labor-intensive industries in rural areas to accelerate shift in labor structure. Simultaneously, to satisfy the demand for skilled labor by modern industries, Vietnam should focus on reforming education system, particularly the tertiary education, with the aim of developing thinking and creative ability.

Moreover, calculation shows that within-industry components contribute considerably to the growth of aggregate labor productivity although they cannot maintain a stable growth rate. Within-industry productivity can be promoted by 
mobilizing, tapping and using effectively all resources and improving business and management capability.

To achieve such aims, Vietnam needs a strong government with ability to build and carry out policies consistently and transparently. Moreover, enterprises should have ability to implement breakthroughs and conduct technological innovations and inventions. The role of government is to support development of enterprises by constructing a sound and accessible information system; designing policy mechanisms for honouring and encouraging enterprises to make long-term investment; protecting intellectual property rights; and creating equal opportunity to access factors of production for all sectors. Meanwhile, enterprises are responsible for making use of government's support to enhance their performance, improve production capacity, and replace technologies to increase labor productivity in their own factories thereby contributing to the growth of aggregate labor productivity.

In short, structural change aiming at the growth of labor productivity is considered as one of core problems in managing socioeconomic development in order to ensure prosperity and sustainable development. By shift-share analysis of structural change that is simple and easy to calculate based on available data appropriate to the fact that data are hard to gather and time series are not long enough in such developing countries as Vietnam, the research offers results that can help review opinions about the correlationship between the growth of aggregate labor productivity and structural change. The method's drawback, however, is its poor ability to offer predictions for the future, so this correlationship needs to be studied with other methods

\section{References}

ADB (2012), "Key Indicators for Asia and the Pacific 2012", retrieved from www.adb.org/statistics on March 14, 2013.

Baumol, W. (1967), "Macroeconomics of Unbalanced Growth: The Anatomy of Urban Crisis", The American Economic Review, pp. 415 - 426.

Chenery, H. et al. (1986), Industrialization and Growth: A Comparative Study, Oxford University Press, New York.

Dũng Hiếu (2012), "Năng suất lao động tại Việt Nam thuộc hàng đáy khu vực" (Vietnam labor productivity is of the lowest in the region), retrieved from www.vneconomy.vn on March 14, 2013. 
Fabricant, S. (1942), Employment in Manufacturing 1899 - 1939, National Bureau of Economic Reseach, New York.

Fagerberg, J. (2000), “Technological Progress, Structural Change and Productivity Growth in Manufacturing: A Comparative Study", Structural Change and Economic Dynamics, Elsevier, vol. 11(4), pp. $393-411$.

GSO (2013), Niên giám thống kê 2012 (Statistical Yearbooks 2012), Thống Kê Publisher, Hà Nội.

Lê Phái (2010), "Nhận diện năng lực cạnh tranh của Việt Nam" (Identifying Vietnam Competitiveness), retrieved from http://www.baomoi.com on March 14, 2013.

Nafziger, E. Wayne (1998), Kinh tế học của các nước đang phát triển (translated from The Economics of Developing Countries), Thống Kê Publisher, Hà Nội.

Nguyễn Tấn Dũng (2011), “Thực hiện tốt 3 khâu đột phá chiến lược mà Đại hội Đảng toàn quốc lần thứ XI đề ra là nhiệm vụ trọng tâm của Chính phủ nhiệm kỳ 2011 - 2016”, retrieved from www.thanhnien.com.vn on March 14, 2013.

Nguyễn Thị Lan Hương (2007), "Phân tích tác động của chuyển dịch cơ cấu ngành kinh tế tới tăng trưởng kinh tế ở Việt Nam" (An analysis of impact of economic structural changes on economic growth in Vietnam), Nghiên cúu Kinh tế, No. 353, pp. 3-11.

Phạm Ngọc Linh \& Nguyễn Thị Kim Dung (2011), Giáo trình Kinh tế phát triển (Development Economics Textbook), National Economics University Publisher, Hà Nội.

Syrquin, M. (1984), "Resource Allocation and Productivity Growth”, in Syrquin, M., L. Taylor \& L. E. Westphal (Eds), Economic Structure and Performance - Esssays in Honor of Hollis B. Chenery, Academic Press, Orlando, Florida, pp. 75 - 111.

Timmer, M. \& A. Szirmai (2000), "Productivity Growth in Asian Manufacturing: The Structural Bonus Hypothesis Examined”, Structural Change and Economic Dynamics, pp. 371 - 392.

Trần Xuân Cầu \& Mai Quốc Chánh (2012), Giáo trình Kinh tế Nguồn nhân lực (Human resource Economics Textbook), National Economics University Publisher, Hà Nội. 